Arq. Bras. Med. Vet. Zootec., v.68, n.3, p.636-640, 2016

\title{
Estradiol and progesterone fecal metabolites analysis in crab-eating-fox (Cerdocyoun thous)
}

\author{
[Análise de metabólitos fecais de estradiol e progesterona em cachorro-do-mato \\ (Cerdocyoun thous)] \\ R.C.R. Paz ${ }^{1}$, N.P. Souza ${ }^{1}$, P.V. Furtado ${ }^{2}$, J.L. Brown ${ }^{3}$ \\ ${ }^{1}$ Faculdade de Agronomia, Medicina Veterinária e Zootecnica - Universidade Federal de \\ Mato Grosso - UFMT - Cuiabá, MT \\ ${ }^{2}$ Laboratório de Endocrinologia - PROVET - Moema, SP \\ ${ }^{3}$ Center for Species Survival, Smithsonian Conservation Biology Institute, 1500 \\ Remount Road, Front Royal, VA, 22630, USA.
}

\begin{abstract}
In this study, four crab-eating fox females (Cerdocyon thous) maintained at the Federal University of Mato Grosso Zoo, Cuiabá, Brazil, were investigated for 12 months, using feces measurement of estradiol and progesterone concentrations. Fecal collections were performed three times a week for hormone extraction. Two methods of analysis, Elisa (EIA) and Radioimmunoassay (RIA), were used in the measurement of progesterone (P4) and estradiol (E2) metabolites. The aim of this study was to compare and validate two different methods of hormone measurement for $\mathrm{C}$. thous. There were no differences regarding the method used. The Radioimmunoassay technique proved to be more sensitive, however, both showed similar results.
\end{abstract}

Keywords: radioimmunoassay, Elisa, estradiol, progesterone, fecal

\section{RESUMO}

Neste estudo, quatro fêmeas de cachorros-do-mato (Cerdocyon thous) mantidas no Zoológico da Universidade Federal de Mato Grosso, Cuiabá, MT, Brasil, foram investigadas pelo período de 12 meses, mediante a mensuração de concentrações de estradiol e progesterona em fezes. Coletas de fezes foram realizadas três vezes por semana para posterior extração hormonal. Dois métodos de análise de metabólitos fecais, elisaimunoensaio (EIA) e radioimunoensaio (RIA), foram utilizados na mensuração dos metabólitos de progesterona (P4) e estradiol (E2). O objetivo deste estudo foi comparar e validar dois diferentes métodos de mensuração hormonal para C. thous. Não houve diferença significativa com relação ao método empregado. A técnica de radioimunoensaio demonstrou ser mais sensível, no entanto ambas apresentaram resultados semelhantes.

Palavras-chave: radioimunoensaio, elisaimunoensaio, estradiol, progesterona, fezes

\section{INTRODUCTION}

Belonging to the Canidae family, the crab-eating fox (Cerdocyon thous) is the most common wild Brazilian canid. It lives throughout much of South America, playing an important role as a seed disperser and controlling rodent populations (Rocha et al., 2004; Pedó et al., 2006). Despite the fact that it is a common species, little research has been carried out on the reproduction of C. thous (Pinheiro Souza et al., 2012).

Although blood concentrations of ovarian gonadal steroids are the most accurate reflection of their secretion, repeated collections of blood samples are generally impractical in wild animals, since restraint-induced stress compromises the animal's health, and affects

Recebido em 5 de agosto de 2014

Aceito em 14 de dezembro de 2015

E-mail: reginacrpaz@gmail.com 
concentrations of gonadal steroids. Therefore, extraction and assay of hormones or other metabolites in feces and urine are of great importance in research centers and zoos, as virtually an unlimited number of samples can be collected without physical or chemical restraint (Graham et al.,1995; Schwarzenbergeret al., 1996a; Brown et al.,1997; Schwarzenberger, 2007).

The aim of the present study was to acquire new knowledge regarding different techniques for measurement of reproductive hormones in crabeating fox (C. thous) females. The specific objectives were to compare two techniques: Elisa (EIA) and Radioimmunoassay (RIA) for monitoring the reproductive cycle with a noninvasive technique, analyzing fecal metabolites of progesterone (P4) and estradiol (E2).

\section{MATERIAL AND METHODS}

The study was carried out with four C. thous females maintained at the Federal University of Mato Grosso Zoo, Cuiabá, MT, Brazil, during a 12 month interval. Twice daily (morning and afternoon), these foxes were fed commercial dog food, fruits (papaya and banana), and raw meat, with ad libitum access to water. All procedures were approved by the Committee for Ethics in Animal Research of the University (23108.002900/08-3) and SISBIO/IBAMA (11167-1).

For fecal steroids, analyses samples of feces (for determination of steroid hormone concentrations) were collected thrice weekly, between 7:00 and 8:00. Samples were put into individual plastic bags, identified, and stored at $-20^{\circ} \mathrm{C}$. Fecal hormone extraction was performed as described by (1996b), with minor modifications. Fecal samples were thawed and mixed. Then, $0.5 \mathrm{~g}$ was placed in a glass tube with $5.0 \mathrm{~mL}$ of $80 \%$ methanol and homogenized. Tubes were vortexed $(30 \mathrm{~s})$ and gently homogenized for $15 \mathrm{~h}$. Subsequently, samples were centrifuged $(1,300 \mathrm{~g}$ for $15 \mathrm{~min}$ ) and the supernatant kept in a water bath at $60^{\circ} \mathrm{C}$ until total evaporation of the $80 \%$ methanol.

Radioimmunoassay (RIA) samples were resuspended in $1.0 \mathrm{~mL}$ of methanol (PA) and diluted in a gelatin buffer [NaPO4 (13.8 g), NaCl $(9.0 \mathrm{~g})$, sodium azide $(1.0 \mathrm{~g})$ and distilled water $(1$
L), $\mathrm{pH}$ 7.0]. For measurement of P4 and E2 fecal metabolite concentrations, a solid phase RIA (Coat-a-Count, Siemens, Los Angeles, CA, USA), was conducted at the PROVET Laboratory, São Paulo, SP, Brazil. These assays were originally developed for quantitative evaluation of P4 and E2 human serum. Quality control of the hormonal assays was determined by intra- and interassay CVs. The percentage of B/B0 binding, sensitivity, and minimum dose detected were analyzed. For fecal matrix assays, a set of control samples that were measured in all hormonal tests was used, as these samples were submitted for extraction and dilution.

The P4 and E2 EIA were conducted at the Center for Species Survival, Smithsonian Conservation Biology Institute/USA.

For P4 EIA $25 \mu \mathrm{L}$ of progesterone CL425 antibody (Coralie Munro, UC Davis, California) in coating buffer $[\mathrm{Na} 2 \mathrm{CO} 3(1.59 \mathrm{~g}), \mathrm{NaHCO} 3$ (2.93g), H2O Mili-Q (1L), pH (9.6)] (1:10,000) was pipetted on to NUNC microtitre plates and incubated overnight at $4^{\circ} \mathrm{C}$. Plates were washed five times with MilliQH2O/Tween 20 (1:500,000), then standards $(4-200 \mathrm{pg} /$ well $)$, low and high controls, each sample in duplicate and progesterone HRP (Coralie Munro) in assay buffer [Tris $(2.42 \mathrm{~g}), \mathrm{NaCl}(17.9 \mathrm{~g}), \mathrm{BSA}(1 \mathrm{~g})$, Tween 80 (1mL) H2O Mili-Q (1L), pH (7.5)] $(1: 20,000)$ was pipetted into the microtiter plate wells and incubated for $2 \mathrm{~h}$ at room temperature. Plates were washed again with MilliQH2O/Tween 20 and $100 \mu \mathrm{L}$ of $40 \mu \mathrm{L} 0.5$ $\mathrm{H} 2 \mathrm{O} 2,125 \mu \mathrm{L} 40 \mathrm{mM}$ ABTS and $12.5 \mathrm{~mL}$ substrate buffer was added to each well. The absorbance was measured at $450 \mathrm{~nm} / 540 \mathrm{~nm}$, using a DYNEX MRX reader (Dynex Technologies, Chantilly, VA, USA).

For E2 EIA, $20 \mu \mathrm{L}$ of estrone conjugate R522-2 antibody (Coralie Munro, UC Davis, California) in coating buffer [Na2CO3 (1.59g), NaHCO3 (2.93g), H2O Mili-Q (1L), pH (9.6)] (1:40,000) was pipetted onto NUNC microtitre plates and incubated overnight at $4^{\circ} \mathrm{C}$. Plates were washed five times with MilliQH2O/Tween 20 $(1: 500,000)$, then standards $(10-200 \mathrm{pg} /$ well $)$, low and high controls, each sample in duplicate and estrone conjugate HRP (Coralie Munro) in assay buffer [Tris (2.42g), $\mathrm{NaCl}(17.9 \mathrm{~g}), \mathrm{BSA}$ (1g), Tween 80 (1mL) H2O Mili-Q (1L), pH (7.5)] $(1: 20,000)$ was pipetted into the microtiter 
plate wells and incubated for $2 \mathrm{~h}$ at room temperature. Plates were washed again with MilliQH2O/Tween 20 and $100 \mu \mathrm{L}$ of $40 \mu \mathrm{L} 0.5$ $\mathrm{H} 2 \mathrm{O} 2,125 \mu \mathrm{L} 40 \mathrm{mM}$ ABTS and $12.5 \mathrm{~mL}$ substrate buffer was added to each well. The absorbance was measured at $450 \mathrm{~nm} / 540 \mathrm{~nm}$, using a DYNEX MRX reader (Dynex Technologies, Chantilly, VA, USA).

\section{RESULTS AND DISCUSSION}

Validation of commercial kits for use in feces matrix for both hormones in this species was performed by the parallelism method using an integral matrix. There was parallelism between the commercial kit curve and dilution curve of the matrix studied.

Sensitivity and percentage of binding assay for P4 was $0.01 \mathrm{ng} / \mathrm{mL}$ and $94 \%$, and for E2 it was $1.73 \mathrm{pg} / \mathrm{mL}$ and $94 \%$. The highest limit of the assays was $40.0 \mathrm{ng} / \mathrm{mL}$ and $3.6 \mathrm{pg} / \mathrm{mL}$ for $\mathrm{P} 4$ and E2, respectively.

The fecal extract pool result across all assays was $7.0 \%$ for P4 and $9.58 \%$ for E2. The intra- and inter assay coefficients of variation for the assay were 9.78 and $5.46 \%(\mathrm{P} 4)$ and 5.60 and $1.19 \%$ (E2), respectively. Based on the hormonal assays of fecal metabolites, both P4 and E2 metabolites were excreted in the feces of $C$. thous.

In this study, the mean peak of fecal P4 and E2 metabolites were $2.37-1.42 \mathrm{ng} / \mathrm{g}$ and 157.95 $82.63 \mathrm{pg} / \mathrm{g}$, respectively.

Validation is used to check the amount of hormone detected and possible interference in the assay. The first step for validation is verifying the parallelism with the standard curve. The standard curve indicates the sensitivity of the test, checking the correlation between the amount of hormone detected and correct dilution of the sample. Recovery tests are used to verify a possible interference and indicate how the concentration measured corresponds to the real concentration.

The parallelism should indicate the correlation coefficient (r) near 1, being considered acceptable values of recovery from 0.85 to 1.15 (Brown, 2008), and 0.9 to 1.10 (Graham, 2001). In our essay was verified parallelism between the standard diagnostic set curve and the curve obtained from the pool of female's feces to progesterone and estradiol. The values (r) found were 0.98 for progesterone and 0.99 for estradiol validating the use of commercial diagnostic kits used.

Assay quality control is measured by the coefficient of variation (CV), which can be intra or inter-assay. The intra-assay variation coefficient determines the error associated with dosage of the same sample in one assay (duplicate or triplicate) and the inter-assay determines the error observed when the same sample is dosed in different tests. The intra-and inter-assay coefficients of variation should not exceed 10\% (Brown, 2008).

Causes of change in the intra-assay coefficient of variation generally result from the inadequate presence of sample or tracer element, and may also be caused by insufficient mixing of the sample or reagents or pipetting errors. Causes for change in inter-assay coefficient of variation can be instability of the reagents or errors on the standard curve (Brown, 2008).

In this experiment the intra and inter-assay variation coefficients did not exceed $10 \%$, indicating that the procedure was performed within the expected quality criteria.

Figure 1 shows the graphics for fecal estradiol and progesterone metabolite dosages using RIA and EIA techniques in four Cerdocyoun thous females. 


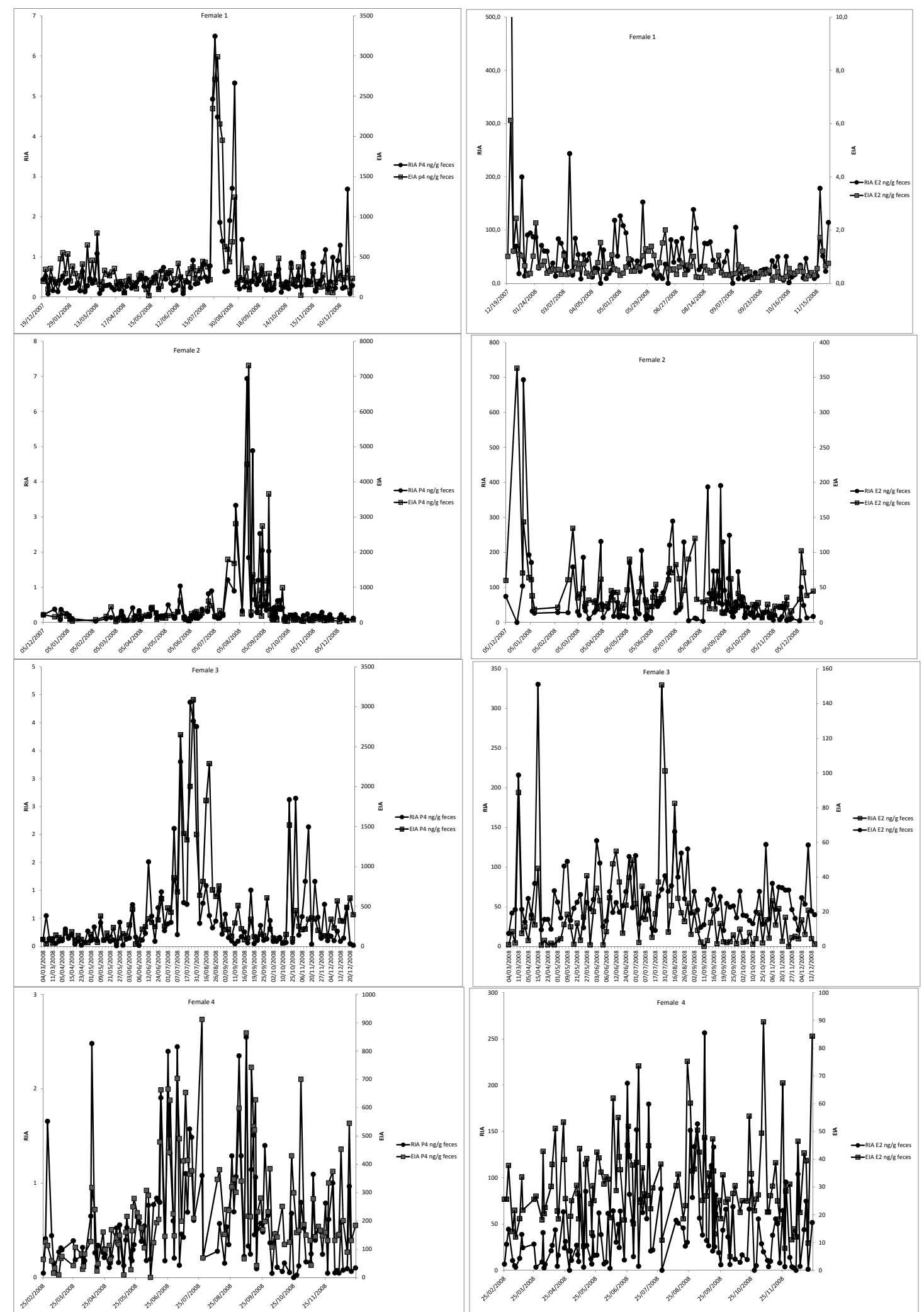

Figure 1. P4 (left) and E2 (right) RIA and EIA results for crab-eating fox (Cerdocyon thous) fecal analysis. 


\section{CONCLUSION}

There were no differences regarding the method used. The Radioimmunoassay technique proved to be more sensitive; however, both showed similar results.

\section{ACKNOWLEDGMENTS}

We thank UFMT Zoo staff for providing a crabeating fox for the experiments. We are also grateful to Sara Putman and Nicole Presley for patient laboratory assistance. This research was funded by FAPEMAT, CAPES and SMITHSONIAN CBI.

\section{REFERENCES}

BROWN, J.L.; WILDT, D.E. Assessing reproductive status in wild felids by non-invasive faecal steroid monitoring. Int. Zoo Yearbook., v.35, p.173-191, 1997.

BROWN, J.L. Endocrine manual for hormonal assessment of wildlife species. Front Royal, VA: Endocrine Research Laboratory, Conservation \& Research Center, National Zoological Park, 2008. 65p. (Apostila).

GRAHAM, L.; GOODROWE, K.L.; RAESIDE, J.I.; LIPTRAP, R.M. Noninvasive monitoring of ovarian function in several felid species by measurement of fecal estradiol-17 and progestins. Zoo. Biol.,v.14, p.223-237,1995.

GRAHAM, L.H. Non invasive monitoring of reproductive hormones in zoo and wildlife species. Jaboticabal: UNESP/Faculdade de Ciências Agrárias e Veterinárias, 2001. 18p. (Apostila).
PEDÓ, E.; TOMAZZONI, A.C.; HERTZ, S.M.; CHRISTOFF, A.U. Diet of crab-eating fox, Cerdocyon thous (Linnaeus) (Carnivora, Canidae), in a suburban area of southern Brazil. Rev. Bras. Zool., v.23, p.637-641,2006.

PINHEIRO SOUZA, N.P.; FURTADO, P.V.; PAZ, R.C.R. Non-invasive monitoring of the estrous cycle in captive crab-eating foxes (Cerdocyon thous). Theriogenology, v.15, p.233239, 2012.

ROCHA, V.J.; REIS, N.R.; SEKIAMA, M.L. Dieta e dispersão de sementes por Cerdocyon thous (Linnaeus) (Carnívora, Canidae), em um fragmento florestal no Paraná, Brasil. Rev. Bras. Zool., v.21, p.871- 876, 2004.

SCHWARZENBERGER, F.; MÖSTL, E.; PALME, R.; BAMBERG, E. Faecal steroid analysis for non-invasive monitoring of reproductive status in farm, wild and zoo animals. Anim. Reprod. Sci., v.42, p.515-552, 1996a.

SCHWARZENBERGER， F.; SON， C.H.; PRETTING, R.; ARBEITER, K. Use of groupspecific antibodies to detect fecal progesterone metabolites during the estrus cycle of cows. Theriogenology, v.46, p.23-32, 1996 b.

SCHWARZENBERGER, F. The many uses of non-invasive faecal steroid monitoring in zoo and wildlife species. Zool. Soc'Y Lond. Anim. Health. Cons., v.41, p.52-74, 2007. 